\title{
Pseudomonas gessardii sp. nov. and Pseudomonas migulae sp. nov., two new species isolated from natural mineral waters
}

\author{
Sophie Verhille, ${ }^{1}$ Nader Baïda, ${ }^{1}$ Fouad Dabboussi, ${ }^{1}$ Monzer Hamze, ${ }^{2}$ \\ Daniel Izard ${ }^{1}$ and Henri Leclerc ${ }^{1}$
}

Author for correspondence: Henri Leclerc. Tel: +333205294 28. Fax: +33320529361 e-mail: leclerc@univ-lille2.fr

1 Service de BactériologieHygiène, Faculté de Médecine Henri Warembourg (pôle recherche), 1 place de Verdun, 59045 Lille Cedex, France

2 Faculté de Santé Publique, Université Libanaise, Tripoli, Lebanon and CNRS Liban, Beirut, Lebanon
Twenty-five non-identified fluorescent Pseudomonas strains isolated from natural mineral waters were previously clustered into three phenotypic subclusters, XIIIb, XVa and XVc. These strains were characterized genotypically in the present study. DNA-DNA hybridization results and DNA base composition analysis revealed that these strains were members of two new species, for which the names Pseudomonas gessardii sp. nov. (type strain CIP

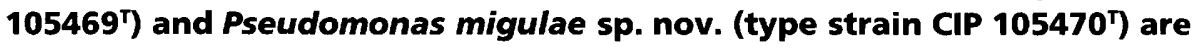
proposed. $P$. gessardii included 13 strains from phenotypic subclusters XVa and XVC. P. migulae included 10 strains from phenotypic subcluster XIIIb. The levels of DNA-DNA relatedness ranged from 71 to $100 \%$ for $P$. gessardii and from 74 to $100 \%$ for $P$. migulae. The $G+C$ content of the DNA of each type strain was $58 \mathrm{~mol} \%$. DNA similarity levels, measured with 67 reference strains of Pseudomonas species, were below $55 \%$, with $\Delta T_{m}$ values of $13{ }^{\circ} \mathrm{C}$ or more. The two new species presented basic morphological characteristics common to all pseudomonads. Various phenotypic features were found to differentiate them: $P$. gessardii strains utilized L-arabitol, myo-inositol, adonitol, xylitol and meso-erythritol as carbon sources, whereas $P$. migulae strains assimilated Larabinose, D-xylose, D-saccharate, meso-tartrate, tricarballylate, D-glucuronate, D-galacturonate, phenylacetate and histamine. The complete 16S rRNA sequences of each type strain were determined and compared with those of the type strains of Pseudomonas species. Finally, a phylogenetic tree was inferred from sequence analysis and demonstrated that the two new species fell into the 'Pseudomonas fluorescens intrageneric cluster'. To date, their clinical significance is unknown.

Keywords: DNA-DNA hybridization, 16S rDNA, Pseudomonas gessardii, Pseudomonas migulae, mineral waters

\section{INTRODUCTION}

The genus Pseudomonas is one of the most complex genera of Gram-negative bacteria. This is why it was chosen by the European "High-Resolution Automated Microbial Identification' (HRAMI) project as a subject for the evaluation of various taxonomic methods (Brosch et al., 1996). Since its creation by Migula (1894), the major obstacle to clear-cut differentiation

The EMBL accession numbers for the 165 rRNA gene sequences of $P$ gessardii CIP $105469^{\top}$ and $P$. migulae CIP $105470^{\top}$ are AF074384 and AF074383. of Pseudomonas from other groups of aerobic, polarflagellated, Gram-negative bacteria has been its heterogeneity. The solution has been to use a variety of taxonomic criteria. Stanier et al. (1966) improved and clarified the situation by using a classification based on physiological and biochemical features, but the major breakthrough for the taxonomy of the genus Pseudomonas has resulted from the increasing use of genetic techniques. DNA-rRNA hybridization experiments carried out by Palleroni et al. (1973) clustered Pseudomonas into five rRNA groups. De Ley (1992) unravelled the taxonomic position of these five rRNA clusters within the general framework of the Gram- 
negative bacteria. This has resulted in the drastic restriction of authentic Pseudomonas species to rRNA group I organisms, because it contains the type species, Pseudomonas aeruginosa. Rearrangement of the genus Pseudomonas has entailed the creation of several new genera, while other species have been reassigned to pre-existing genera, such as Chryseomonas and Flavimonas (Holmes et al., 1987), Burkholderia (Yabuuchi et al., 1992), Ralstonia (Yabuuchi et al., 1995), Comamonas (De Vos et al., 1985), Acidovorax (Willems et al., 1990), Hydrogenophaga (Willems et al., 1989), Telluria (Bowman et al., 1993), Stenotrophomonas (Palleroni \& Bradbury, 1993), Brevundimonas (Segers et al., 1994), Aminobacter (Urakami et al., 1992), Oligotropha (Meyer et al., 1993), Zavarzinia (Meyer et al., 1993), Sphingomonas (Yabuuchi et al., 1990), Herbaspirillum (Baldani et al., 1996) and Devosia (Nakagawa et al., 1996). Nowadays, taxonomy is more and more defined as a system 'that should reflect as closely as possible natural relationships between bacteria, by using chronometer molecules such as RNA 16S' (Vandamme et al., 1996). The natural intrageneric relationships of the genus Pseudomonas sensu stricto have been described by Moore et al. (1996), who delineated two major intrageneric clusters: 'Pseudomonas aeruginosa intrageneric cluster' and 'Pseudomonas fluorescens intrageneric cluster'. At the species level, the genus Pseudomonas sensu stricto includes at least 30 validly described species (Kersters et al., 1996). Pseudomonads are often metabolically versatile and are able to colonize low-nutrient-concentration ecosystems such as mineral waters (Oger et al., 1987; van der Kooij, 1990). Natural mineral waters are characterized by their bacterial flora and their chemical and physical composition (Schwaller \& Schmidt-Lorenz, 1981). However, a few studies have already demonstrated that identification at the species level may be a difficult task and sometimes requires further taxonomic study, including numerical analysis and genomic studies (Coroler et al., 1996; Elomari et al., 1996).

Twenty-five strains that could not be identified at the species level were previously clustered into three phenotypic subclusters (Verhille et al., 1997): subcluster XIIIb (including strain CFML 95-321 $1^{\mathrm{T}}$ ), subcluster XVa (including strain CFML 95-251 ${ }^{\mathrm{T}}$ ) and subcluster XVc.

In this paper, we have characterized these strains genotypically to unravel the finer taxonomic position of these groups within the genus Pseudomonas. According to the outcome of the genomic study (DNADNA hybridization, $\Delta T_{\mathrm{m}}$ and DNA $\mathrm{G}+\mathrm{C}$ content), we propose the description of two new species, Pseudomonas gessardii sp. nov. (type strain CIP $105469^{\mathrm{T}}=$ CFML 95-251 ${ }^{\mathrm{T}}$ ) and Pseudomonas migulae sp. nov. (type strain CIP $105470^{\mathrm{T}}=$ CFML 95-321 ${ }^{\mathrm{T}}$ ).

\section{METHODS}

Bacterial strains. A total of 132 strains belonging to the genus Pseudomonas were investigated in this work. Sixty-five of them were isolated from mineral waters and were previously allocated into the following ten phenotypic clusters or subclusters: IX, X, XI, XIIe, XIIIa, XIIIb, XIIIc, XIIId, XVa and XVc (Verhille et al., 1997). The other 67 strains were type or collection strains of authentic Pseudomonas species included as controls. Details concerning the these strains are given in Tables $2-4$.

Flagellation study. Negative staining was done with fixed cells of the type strains of $P$. gessardii and $P$. migulae according to the method described by Hoeniger (1965).

DNA extraction and purification. Extraction and purification of DNA were performed by the method of Beji et al. (1987).

DNA labelling and DNA-DNA hybridization. Native DNAs were labelled in vitro by nick translation with tritiumlabelled nucleotides (Amersham). The S1 nucleasetrichloroacetic acid method used for hybridizations has been described previously (Grimont et al., 1980). The reassociation temperature was $60^{\circ} \mathrm{C}$. DNA-DNA hybridization experiments were carried out by using labelled DNAs from the type strains of $P$. gessardii (phenotypic subcluster XVa) and $P$. migulae (phenotypic subcluster XIIIb). Each measurement was repeated at least twice and means are shown.

Thermal stability of reassociated DNAs. The temperature at which $50 \%$ of reassociated DNA became hydrolysable by S1 nuclease $\left(T_{\mathrm{m}}\right)$ was determined by the method of Crosa et al. (1973). The $\Delta T_{\mathrm{m}}$ was obtained as the difference between the $T_{\mathrm{m}}$ of the heteroduplex and the $T_{\mathrm{m}}$ of homoduplex.

DNA base composition. $\mathrm{G}+\mathrm{C}$ contents were determined from the denaturation curve using the equation of De Ley (1970).

PCR amplification of 165 rDNA. Amplification of gene fragments encoding 16S rRNA was performed by using the following universal $16 \mathrm{~S}$ rRNA primers described previously by Edwards et al. (1989), PA (5'-AGAGTTTGATCCTGGCTCAG-3') and PH (5'-AAGGAGGTGATCGAGCCGCA-3'), resulting in two overlapping DNA fragments that covered the 16S rRNA gene. One microgram of DNA was subjected to PCR in a total volume of $100 \mu \mathrm{l}$ containing $10 \mu \mathrm{l}$ $10 \times$ buffer $\left[50 \mathrm{mM} \mathrm{KCl}, 10 \mathrm{mM}\right.$ Tris $/ \mathrm{HCl}, 15 \mathrm{mM} \mathrm{MgCl}_{2}$, $10 \%(\mathrm{v} / \mathrm{v})$ glycerol], $0.5 \mu \mathrm{l}$ dNTP cocktail ( $1.25 \mathrm{mM}$ each), $0.5 \mu \mathrm{l}$ each primer $(1 \mu \mathrm{M}) ; 1.5 \mu \mathrm{MgCl}_{2}(75 \mathrm{mM})$ and sterile distilled water to $100 \mu \mathrm{l}$. At least $0.5 \mu \mathrm{l}(2.5 \mathrm{U})$ Taq DNA polymerase was added. Each $100 \mu \mathrm{l}$ mixture was overlaid with three drops of mineral oil and subjected to thermal cycle amplification. A DNA thermal cycler 480 was used (Perkin-Elmer-Cetus) and programmed as follows: (i) an initial temperature of $94^{\circ} \mathrm{C}$ for $5 \mathrm{~min}$ to melt the doublestranded DNA, (ii) 35 cycles of $1 \mathrm{~min}$ at $94^{\circ} \mathrm{C}, 1 \mathrm{~min}$ at $55^{\circ} \mathrm{C}$ and $1 \mathrm{~min}$ at $72^{\circ} \mathrm{C}$, and (iii) $10 \mathrm{~min}$ at $72^{\circ} \mathrm{C}$ to allow extension of any incomplete products. The reaction mixture was held at $4{ }^{\circ} \mathrm{C}$ until it was used. Finally, $2 \mu$ of the amplified fragment was loaded onto a $1.5 \%$ agarose gel for electrophoresis to check that only one band of the expected size was obtained.

The 16S rRNA gene sequences of $P$. gessardii CIP $105469^{\mathrm{T}}$ and $P$. migulae CIP $105470^{\mathrm{T}}$ were determined directly from PCR products in both the forward and reverse directions. An ABI 377 automated sequencer was used (Perkin-Elmer).

Analysis of sequence data. The two sequences generated were aligned with the $16 \mathrm{~S}$ rDNA sequences of type strains of 
Two new Pseudomonas species from mineral waters

Table 1. Type strains included in the phylogenetic tree

Culture collections are abbreviated as: IAM, Institute of Applied Microbiology, University of Tokyo, Tokyo, Japan; ATCC, American Type Culture Collection, Mannassas, VA, USA; CCUG, Culture Collection, University of Göteborg, Göteborg, Sweden; CIP, Collection de l'Institut Pasteur, Paris, France; DSMZ, Deutsche Sammlung von Mikroorganismen und Zellkulturen, Braunschweig, Germany; NCPPB, National Collection of Plant-pathogenic Bacteria, Harpenden, UK; LMG, Laboratorium voor Microbiologie, Rijksuniversiteit Gent, Gent, Belgium.

\begin{tabular}{|c|c|c|}
\hline Species & Strain & $\begin{array}{c}\text { EMBL } \\
\text { accession no. }\end{array}$ \\
\hline$P$. gessardii & CIP $105469^{\mathrm{T}}$ & AF074384 \\
\hline P. migulae & CIP $105470^{\mathrm{T}}$ & AF074383 \\
\hline P. aeruginosa & DSMZ $50071^{\mathrm{T}}$ & X06684 \\
\hline$P$. agarici & LMG $2112^{\mathrm{T}}$ & Z76652 \\
\hline$P$. alcaligenes & LMG $1224^{\mathrm{T}}$ & Z76653 \\
\hline P. amygdali & LMG $2123^{\mathrm{T}}$ & Z76654 \\
\hline$P$. asplenii & LMG $2137^{\mathrm{T}}$ & $Z 76655$ \\
\hline P. balearica & DSMZ $6083^{\mathrm{T}}$ & U26418 \\
\hline P. caricapapayae & ATCC $33615^{\mathrm{T}}$ & D84010 \\
\hline P. chlororaphis & IAM $12354^{\mathrm{T}}$ & D84011 \\
\hline P. cichorii & LMG $2162^{\mathrm{T}}$ & Z76658 \\
\hline P. citronellolis & DSMZ 50332 & Z76659 \\
\hline 'P. coronafaciens' & LMG $13190^{\mathrm{T}}$ & $Z 76660$ \\
\hline P. corrugata & ATCC $29736^{\mathrm{T}}$ & D84012 \\
\hline P. ficuserectae & LMG $5694^{\mathrm{T}}$ & Z76661 \\
\hline P. flavescens & NCPPB $3063^{\mathrm{T}}$ & U01916 \\
\hline P. fluorescens biovar I & DSMZ $50090^{\mathrm{T}}$ & Z76662 \\
\hline P. libanensis & CIP $105460^{\mathrm{T}}$ & AF057645 \\
\hline $\begin{array}{l}\text { P. marginalis } \mathrm{pv} . \\
\text { marginalis }\end{array}$ & LMG $2210^{\mathrm{T}}$ & Z76663 \\
\hline P. mendocina & LMG $1223^{\mathrm{T}}$ & Z76664 \\
\hline P. monteilii & CIP $104883^{\mathrm{T}}$ & AF064458 \\
\hline P. mucidolens & IAM $12406^{\mathrm{T}}$ & D84017 \\
\hline P. oleovorans & DSMZ $1045^{\mathrm{T}}$ & $Z 76665$ \\
\hline P. pseudoalcaligenes & LMG $1225^{\mathrm{T}}$ & Z76666 \\
\hline P. putida & $\operatorname{DSMZ} 291^{\mathrm{T}}$ & Z76667 \\
\hline$P$. resinovorans & $\mathrm{LMG} 2274^{\mathrm{T}}$ & Z76668 \\
\hline P. rhodesiae & CIP $104664^{\mathrm{T}}$ & AF064459 \\
\hline P. stutzeri & CCUG $11256^{\mathrm{T}}$ & U26262 \\
\hline P. synxantha & IAM $12356^{\mathrm{T}}$ & D84025 \\
\hline P. syringae & LMG $1247 \mathrm{tl}^{\mathrm{T}}$ & Z76669 \\
\hline P. taetrolens & IAM $1653^{\mathrm{T}}$ & D84027 \\
\hline P. tolaasii & LMG $2342^{\mathrm{T}}$ & $\mathrm{Z} 76670$ \\
\hline$P$. veronii & CIP $104663^{\mathrm{T}}$ & AF064460 \\
\hline P. viridiflava & LMG $2352^{\mathrm{T}}$ & Z76671 \\
\hline
\end{tabular}

Pseudomonas species listed by Kersters et al. (1996) that were available in GenBank. These strains and their accession numbers are listed in Table 1 . The multiple alignment was performed by using the CLUSTAL $x$ program (a more up-todate version of CLUSTAL w; Thompson et al., 1994). A distance tree was constructed by the neighbour-joining method, correcting for multiple substitutions and excluding positions with gaps (Saitou \& Nei, 1987). The tree was based on a complete alignment of 16S rRNA sequences from 34 strains. These strains have been grouped according to the 16S rRNA sequence data of Kersters et al. (1996) (various Pseudomonas type strains), Coroler et al. (1996) (Pseudomonas rhodesiae), Elomari et al. (1996) (Pseudomonas veronii), Elomari et al. (1997) (Pseudomonas monteilii), and Dabboussi et al. (1999) (Pseudomonas libanensis CIP $105460^{\mathrm{T}}$ ). The tree topology was tested by a bootstrap analysis of 1000 resamplings (Felsenstein, 1985). Due to gaps and alignment problems, 1325 nucleotides were used in the calculation of identities between 16S rRNA sequences.

\section{RESULTS}

\section{Phenotypic data}

Strains CIP $105469^{\mathrm{T}}$ (type strain of P. gessardii) and CIP $105470^{\mathrm{T}}$ (type strain of $P$. migulae) are motile by means of single polar flagella (Fig. 1). The phenotypic characteristics of mineral-water strains studied in this work have been published previously (Verhille et al., 1997).

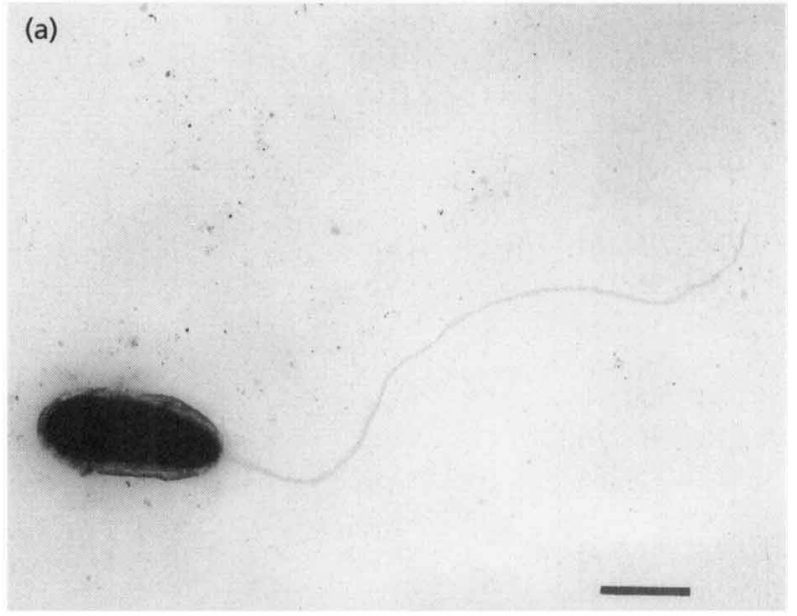

(b)

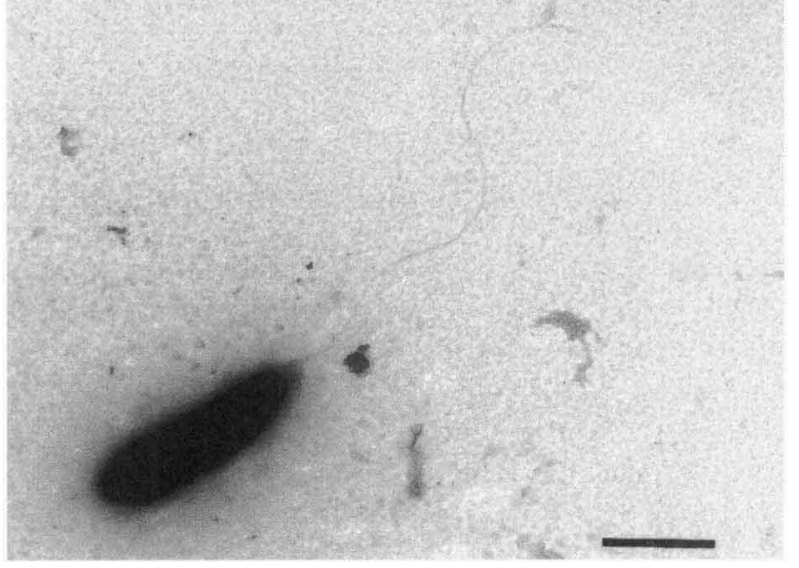

Fig. 1. Electron micrographs of cells of $P$. gessardii CIP $105469^{\top}$ (a) and $P$. migulae CIP $105470^{\top}$ (b) showing the single polar flagella. Bars, $1 \mu \mathrm{m}$. 
Table 2. DNA-DNA hybridization values between $P$. migulae CIP $105470^{\top}, P$. gessardii CIP $105469^{\top}$ and phenotypically related species

Phenotypic clusters are as given by Verhille et al. (1997). Strains CFML 95-326 and CFML 95-323 do not belong to P. migulae. CFML, Collection de la Faculté de Médecine, Lille, France; CIP, Collection de l'Institut Pasteur, Paris, France. RBR, Relative binding ratio;--, not determined.

\begin{tabular}{|c|c|c|c|c|c|c|}
\hline \multirow[t]{3}{*}{ Strain } & \multirow{3}{*}{$\begin{array}{l}\text { Phenotypic } \\
\text { subcluster }\end{array}$} & \multicolumn{4}{|c|}{ Labelled DNA } & \multirow{3}{*}{$\begin{array}{c}G+C \text { conten } \\
(\mathrm{mol} \%)\end{array}$} \\
\hline & & \multicolumn{2}{|c|}{ CIP $105470^{T}$} & \multicolumn{2}{|c|}{ CIP $105469^{\mathrm{T}}$} & \\
\hline & & RBR (\%) & $\Delta T_{\mathrm{m}}\left({ }^{\circ} \mathrm{C}\right)$ & $\operatorname{RBR}(\%)$ & $\Delta T_{\mathrm{m}}\left({ }^{\circ} \mathrm{C}\right)$ & \\
\hline \multicolumn{7}{|l|}{ P. migulae } \\
\hline $\begin{array}{l}\text { CIP } 105470^{\mathrm{T}} \\
\left(=\text { CFML } 95-321^{\mathrm{T}}\right)\end{array}$ & XIIIb & 100 & 0 & 31 & - & 58 \\
\hline CFML $95-341$ & XIIIb & 99 & - & 26 & - & - \\
\hline CFML $95-320$ & XIIIb & 98 & - & 25 & - & - \\
\hline CFML 95-318 & XIIIb & 97 & 0 & 26 & - & - \\
\hline CFML 95-316 & XIIIb & 88 & - & 27 & - & 59 \\
\hline CFML $95-333$ & XIIIb & 88 & - & 27 & - & - \\
\hline CFML 95-327 & XIIIb & 87 & - & 23 & - & - \\
\hline CFML 95-317 & XIIIb & 87 & 1 & 28 & - & - \\
\hline CFML 95-324 & XIIIb & 83 & 2 & 25 & - & 58 \\
\hline CFML 95-263 & XIIIb & 74 & 2 & 21 & - & - \\
\hline CFML 95-326 & XIIIb & 61 & 13 & 56 & 10 & - \\
\hline CFML 95-323 & XIIIb & 56 & 9 & 26 & - & - \\
\hline \multicolumn{7}{|l|}{$P$. gessardii } \\
\hline $\begin{array}{l}\text { CIP } 105469^{\mathrm{T}} \\
\left(=\text { CFML } 95-251^{\mathrm{T}}\right)\end{array}$ & $\mathrm{XVa}$ & 28 & - & 100 & 0 & 58 \\
\hline CFML 95-244 & $X V a$ & - & - & 94 & - & - \\
\hline CFML 95-332 & $\mathrm{XVc}$ & 32 & - & 90 & - & - \\
\hline CFML 95-258 & $\mathrm{XVa}$ & - & - & 88 & - & - \\
\hline CFML 95-338 & $\mathrm{XVc}$ & 33 & - & 82 & 1 & - \\
\hline CFML $95-250$ & $\mathrm{XVa}$ & - & - & 81 & - & - \\
\hline CFML 95-256 & XVa & - & - & 78 & - & - \\
\hline CFML 95-264 & $\mathrm{XVa}$ & 16 & - & 77 & - & - \\
\hline CFML 95-254 & $\mathrm{XVa}$ & - & - & 76 & - & 58 \\
\hline CFML 95-342 & $\mathrm{XVc}$ & - & - & 75 & - & 58 \\
\hline CFML 95-245 & $\mathrm{XVa}$ & 23 & - & 75 & 1 & - \\
\hline CFML $95-331$ & $\mathrm{XVc}$ & - & - & 73 & 1 & - \\
\hline CFML 95-255 & $\mathrm{XVa}$ & - & - & 71 & 2 & - \\
\hline
\end{tabular}

\section{DNA-DNA hybridization}

The DNA-binding ratios between the type strains of $P$. gessardii CIP $105469^{\mathrm{T}}\left(=\right.$ CFML $95-251^{\mathrm{T}}$, phenotypic subcluster XVa), P. migulae CIP $105470^{\mathrm{T}}$ (= CFML 95-321 ${ }^{\mathrm{T}}$, phenotypic subcluster XIIIb) and 65 isolates from mineral waters are given in Tables 2 and 3.

When the DNA of $P$. gessardii CIP $105469^{\mathrm{T}}$ was used as the labelled probe, levels of reassociation with DNA from 13 strains from phenotypic subclusters XVa and $\mathrm{XVc}$ ranged from 71 to $100 \%$. The $\Delta T_{\mathrm{m}}$ values measured within this genomic group were $2{ }^{\circ} \mathrm{C}$ or less (Table 2). DNA-DNA similarity levels between strain CIP $105469^{\mathrm{T}}$ and other strains from mineral waters included in the previously described clusters or subclusters (IX, X, XI, XIIe, XIIIa, XIIIb, XIIIc and
XIIId) ranged from 20 to $59 \%$ (Tables 2 and 3). The $\Delta T_{\mathrm{m}}$ values obtained for strains from mineral waters that gave DNA similarity values of $50-69 \%$ to strain CIP $105469^{\mathrm{T}}$ were $6{ }^{\circ} \mathrm{C}$ or more. Finally, DNA-DNA hybridizations between strain CIP $105469^{\mathrm{T}}$ and other previously described species of the genus Pseudomonas yielded hybridization values below $49 \%$ (Table 4 ).

The levels of DNA-DNA hybridization between $P$. migulae CIP $105470^{\mathrm{T}}$ and the other 11 isolates belonging to the same subcluster, XIIIb, ranged from 56 to $100 \%$. Ten strains of this subcluster were $74-100 \%$ related to strain CIP $105470^{\mathrm{T}}$, with $\Delta T_{\mathrm{m}}$ values of $2{ }^{\circ} \mathrm{C}$ or less (Table 2). The two remaining strains of subcluster XIIIb, CFML 95-326 and CFML 95-323, gave only low DNA similarity levels (61 and $56 \%$, 
Table 3. DNA-DNA hybridization values between $P$. gessardii CIP $105469^{\top}$, P. migulae CIP $105470^{\top}$ and other strains isolated from mineral waters

Phenotypic clusters and subclusters are as given by Verhille et al. (1997). RBR, Relative binding ratio;--, not determined.

\begin{tabular}{|c|c|c|c|c|}
\hline \multirow[t]{3}{*}{ Strain } & \multicolumn{4}{|c|}{ Labelled DNA } \\
\hline & \multicolumn{2}{|c|}{$\begin{aligned} & \text { CIP 105469 } \\
(= & \left.\text { CFML } 95-251^{T}\right)\end{aligned}$} & \multicolumn{2}{|c|}{$\begin{array}{c}\text { CIP 105470 } \\
\left(=\text { CFML } 95-321^{T}\right)\end{array}$} \\
\hline & RBR (\%) & $\Delta T_{\mathrm{m}}\left({ }^{\circ} \mathrm{C}\right)$ & RBR (\%) & $\Delta T_{\mathrm{m}}\left({ }^{\circ} \mathrm{C}\right)$ \\
\hline \multicolumn{5}{|c|}{ Phenotypic cluster IX } \\
\hline CFML 95-307 & 23 & - & 39 & - \\
\hline CFML 95-311 & 36 & - & 19 & - \\
\hline CFML 95-312 & 39 & - & 38 & - \\
\hline CFML 95-306 & 35 & - & 29 & - \\
\hline CFML 95-308 & 33 & - & 17 & - \\
\hline CFML 95-303 & 26 & - & 50 & 9 \\
\hline CFML 95-309 & 43 & - & 19 & - \\
\hline CFML 95-305 & 36 & - & 15 & - \\
\hline CFML 95-304 & 20 & - & 11 & - \\
\hline CFML 95-322 & 25 & - & 30 & - \\
\hline \multicolumn{5}{|c|}{ Phenotypic cluster X } \\
\hline CFML $95-285$ & 33 & - & 46 & - \\
\hline CFML 95-280 & 22 & - & 51 & 9 \\
\hline CFML 95-281 & 25 & - & 54 & 10 \\
\hline \multicolumn{5}{|c|}{ Phenotypic cluster XI } \\
\hline CFML 95-325 & 59 & 8 & 35 & - \\
\hline CFML 95-319 & 52 & 9 & 29 & - \\
\hline CFML $95-340$ & 38 & - & 34 & - \\
\hline CFML 95-270 & 36 & - & 49 & - \\
\hline CFML $95-329$ & 35 & - & 41 & - \\
\hline \multicolumn{5}{|c|}{ Phenotypic subcluster XIIe } \\
\hline CFML 95-335 & 57 & 8 & 31 & - \\
\hline CFML 95-334 & 40 & - & 30 & - \\
\hline CFML 95-330 & 37 & - & 31 & - \\
\hline CFML 95-339 & 36 & - & 44 & - \\
\hline CFML 95-275 & 32 & - & 41 & - \\
\hline CFML 95-336 & 27 & - & 27 & - \\
\hline CFML 95-337 & 24 & - & 42 & - \\
\hline \multicolumn{5}{|c|}{ Phenotypic subcluster XIIIa } \\
\hline CFML 95-313 & 33 & - & 26 & - \\
\hline CFML 95-302 & 36 & - & 16 & - \\
\hline CFML 95-314 & 28 & - & 28 & - \\
\hline CFML $95-310$ & 35 & - & 20 & - \\
\hline \multicolumn{5}{|c|}{ Phenotypic subcluster XIIIc } \\
\hline CFML 95-260 & 31 & - & 48 & - \\
\hline CFML 95-259 & 41 & - & 16 & - \\
\hline CFML 95-246 & 40 & - & 26 & - \\
\hline CFML 95-243 & 37 & - & 24 & - \\
\hline CFML 95-261 & 38 & - & 18 & - \\
\hline CFML 95-315 & 38 & - & 16 & - \\
\hline CFML 95-249 & 31 & - & 43 & - \\
\hline CFML 95-262 & 40 & - & 22 & - \\
\hline CFML 95-257 & 43 & - & 49 & - \\
\hline \multicolumn{5}{|c|}{ Phenotypic subcluster XIIId } \\
\hline CFML 95-282 & 58 & 6 & 37 & - \\
\hline CFML 95-271 & 23 & - & 46 & \\
\hline
\end{tabular}

respectively) with strain CIP $105470^{\mathrm{T}}$, which were confirmed by $\Delta T_{\mathrm{m}}$ values of 13 and $9^{\circ} \mathrm{C}$. When hybridized with strain CIP $105470^{\mathrm{T}}$, the relative binding ratios with strains from mineral waters belonging to other phenotypic groups (IX, X, XI, XIIe, XIIIa, XIIIc and XIIId) were less than $54 \%$, with a $\Delta T_{\mathrm{m}}$ range of $9-10^{\circ} \mathrm{C}$ (Tables 2 and 3 ). Finally, DNA-DNA similarity levels between strain CIP $105470^{\mathrm{T}}$ and fluorescent or non-fluorescent species belonging or related to the genus Pseudomonas varied from 9 to $55 \%$ (Table 4 ).

Hybridizations were also performed between the two new species, represented by strains CIP $105469^{\mathrm{T}}$ and CIP $105470^{\mathrm{T}}$. Results are listed in Table 2 and varied from 16 to $33 \%$.

\section{DNA G + C content}

The $\mathrm{G}+\mathrm{C}$ contents of DNA from strains $P$. gessardii CIP $105469^{\mathrm{T}}$, CFML 95-324, P. migulae CIP $105470^{\mathrm{T}}$, CFML 95-254 and CFML 95-342 were $58 \mathrm{~mol} \%$. The value calculated for strain CFML 95-316 was $59 \mathrm{~mol} \%$ (Table 2 ).

\section{Analysis of sequence data and phylogenetic analysis}

16S rDNA sequences of 1516 nucleotides were determined for strains $P$. gessardii CIP $105469^{\mathrm{T}}$ and $P$. migulae CIP $105470^{\mathrm{T}}$ by sequencing PCR-amplified DNAs. Percentage identities between strains CIP $105470^{\mathrm{T}}$ and CIP $105469^{\mathrm{T}}$ and type strains of the Pseudomonas species listed by Kersters et al. (1996) were in the range $94.4-99.6 \%$. The closest neighbours of strain CIP $105469^{\mathrm{T}}$ according to $16 \mathrm{~S}$ rDNA sequences were $P$. rhodesiae CIP $104664^{\mathrm{T}}$ and $P$. veronii CIP $104663^{\mathrm{T}}$ ( $99 \cdot 0 \%$ for both) and also Pseudomonas mucidolens IAM $12406^{\mathrm{T}}$ and Pseudomonas synxantha IAM $12356^{\mathrm{T}}(99.6 \%$ for both). As for strain CIP $105470^{\mathrm{T}}$, the highest values were obtained with Pseudomonas corrugata ATCC $29736^{\mathrm{T}}(99 \cdot 2 \%)$ and $P$. veronii CIP $104663^{\mathrm{T}}(99 \cdot 3 \%)$. The phylogenetic tree is displayed in Fig. 2.

\section{DISCUSSION}

A total of 25 strains isolated from natural mineral waters and identified phenotypically as fluorescent pseudomonads were previously clustered into the three phenotypic subclusters XIIIb, XVa and XVc (Verhille et al., 1997). Additional genomic studies were necessary to unravel the taxonomic position of these subclusters within the genus Pseudomonas sensu stricto (Palleroni, 1984). According to Wayne et al. (1987), the phylogenetic definition of a species generally includes strains with 'approximately $70 \%$ or greater DNA-DNA relatedness and with $5^{\circ} \mathrm{C}$ or less $\Delta T_{\mathrm{m}}$.' Therefore, DNA-DNA hybridization experiments performed in this work with strains CFML 95-251 
Table 4. Levels of DNA relatedness between $P$. gessardii CIP $105469^{\top}$, P. migulae CIP $105479^{\top}$ and other strains of the genus Pseudomonas

Relative binding at $60^{\circ} \mathrm{C}$ is shown. Culture collections not given in Table 1 are abbreviated as follows: CCEB, Culture Collection of Entomogenous Bacteria, Institute of Entomology,

Czechoslovak Academy of Sciences, Prague, Czech Republic; CCM, Czechoslovak Collection of Microorganisms, University of Brno, Czech Republic; CFBP, Collection Française de Bactéries Phytopathogènes, INRA, Angers, France; CFML, Collection de la Faculté de Médecine de Lille, Lille, France.

\begin{tabular}{|c|c|c|}
\hline \multirow[t]{2}{*}{ Source of unlabelled DNA } & \multicolumn{2}{|c|}{ Source of labelled DNA } \\
\hline & CIP $105469^{T}$ & CIP $105470^{1}$ \\
\hline P. aeruginosa ATCC $10145^{\mathrm{T}}$ & 9 & 30 \\
\hline P. aeruginosa ATCC 27853 & 27 & 24 \\
\hline$P$. aeruginosa ATCC 15692 & 20 & 15 \\
\hline P. fluorescens biovar I ATCC $13525^{\mathrm{T}}$ & 31 & 40 \\
\hline P. fluorescens biovar I ATCC 17397 & 25 & 20 \\
\hline P. fluorescens biovar I ATCC 17563 & 39 & 41 \\
\hline P. fluorescens biovar II ATCC 17482 & 45 & 31 \\
\hline P. fluorescens biovar II ATCC 17815 & 40 & 40 \\
\hline P. fluorescens biovar II ATCC 17816 & 49 & 29 \\
\hline P. fluorescens biovar II DSMZ 50106 & 33 & 40 \\
\hline P. fluorescens biovar III ATCC 17559 & 46 & 29 \\
\hline P. fluorescens biovar III ATCC 17571 & 36 & 41 \\
\hline P. fluorescens biovar III ATCC 17400 & 23 & 25 \\
\hline P. fluorescens biovar IV DSMZ 50415 & 40 & 44 \\
\hline P. fluorescens biovar IV ATCC 12983 & 25 & 45 \\
\hline P. fluorescens biovar V DSMZ 50148 & 28 & $55^{*}$ \\
\hline P. fluorescens biovar V ATCC 17386 & 21 & 35 \\
\hline P. fluorescens biovar V ATCC 17573 & 34 & 40 \\
\hline P. fluorescens biovar V ATCC 14150 & 37 & 35 \\
\hline P. fluorescens biovar V ATCC 15916 & 43 & 33 \\
\hline P. fluorescens biovar V ATCC 17518 & 40 & 35 \\
\hline P. putida biovar A ATCC $12633^{\mathrm{T}}$ & 14 & 45 \\
\hline P. putida biovar A DSMZ 50208 & 15 & 24 \\
\hline P. putida biovar B ATCC 17430 & 28 & 45 \\
\hline P. putida biovar B CCUG 1317 & 20 & 19 \\
\hline P. putida biovar B ATCC 17484 & 35 & $54^{*}$ \\
\hline P. monteilii CIP $104883^{\mathrm{T}}$ & 10 & 15 \\
\hline P. rhodesiae CIP $104664^{\mathrm{T}}$ & 36 & 22 \\
\hline P. veronii CIP $104663^{\mathrm{T}}$ & 33 & 25 \\
\hline P. flavescens CIP $104204^{\mathrm{T}}$ & 38 & 11 \\
\hline P. flavescens CIP 104205 & 35 & 11 \\
\hline P. marginalis ATCC $10844^{\mathrm{T}}$ & 29 & 30 \\
\hline P. marginalis DSMZ 50275 & 43 & 31 \\
\hline P. marginalis DSMZ 50276 & 44 & 34 \\
\hline P. chlororaphis DSMZ 50083 & 29 & 30 \\
\hline P. chlororaphis ATCC 9447 & 39 & 42 \\
\hline P. chlororaphis ATCC 17414 & 32 & 46 \\
\hline P. aureofaciens CCEB $518^{\mathrm{T}}$ & 24 & 34 \\
\hline P. aureofaciens ATCC 17415 & 45 & 33 \\
\hline P. fuscovaginae NCPPB $3085^{\mathrm{T}}$ & 20 & 27 \\
\hline P. lundensis CCM 573 & 14 & 42 \\
\hline P. lundensis CCUG 18758 & 16 & 24 \\
\hline P. syringae ATCC $19310^{\mathrm{T}}$ & 10 & 18 \\
\hline P. savastanoi CFBP $1670^{\mathrm{T}}$ & 8 & 46 \\
\hline P. savastanoi CFBP 2088 & 21 & 30 \\
\hline P. savastanoi CFBP 1838 & 16 & 20 \\
\hline P. viridiflava ATCC $13223^{\mathrm{T}}$ & 24 & 20 \\
\hline
\end{tabular}


Table 4 (cont)

\begin{tabular}{|c|c|c|}
\hline \multirow[t]{2}{*}{ Source of unlabelled DNA } & \multicolumn{2}{|c|}{ Source of labelled DNA } \\
\hline & CIP $105469^{\mathrm{T}}$ & CIP $105470^{\mathrm{T}}$ \\
\hline P. cichorii DSMZ 50259 & 20 & 28 \\
\hline$P$. agarici ATCC $25941^{\mathrm{T}}$ & 18 & 48 \\
\hline P. asplenii ATCC $23835^{\mathrm{T}}$ & 23 & 23 \\
\hline P. caricapapayae NCPPB $1873^{\mathrm{T}}$ & 16 & 37 \\
\hline P. tolaasii NCPPB $2192^{\mathrm{T}}$ & 40 & 33 \\
\hline P. tolaasii NCPPB 1616 & 44 & 41 \\
\hline P. stutzeri ATCC $17588^{\mathrm{T}}$ & 26 & 12 \\
\hline P. stutzeri ATCC 17587 & 14 & 12 \\
\hline P. stutzeri ATCC 17591 & 14 & 12 \\
\hline P. stutzeri ATCC 17686 & 34 & 14 \\
\hline P. mendocina ATCC $25411^{\mathrm{T}}$ & 19 & 13 \\
\hline P. mendocina ATCC 25412 & 32 & 46 \\
\hline$P$. alcaligenes ATCC $14909^{\mathrm{T}}$ & 38 & 19 \\
\hline$P$. pseudoalcaligenes ATCC $17440^{\mathrm{T}}$ & 28 & 9 \\
\hline P. pseudoalcaligenes ATCC 12815 & 15 & 17 \\
\hline P. fragi ATCC $4973^{\mathrm{T}}$ & 12 & 23 \\
\hline P. fragi ATCC 27362 & 18 & 14 \\
\hline P. mucidolens CIP $103298^{\mathrm{T}}$ & 32 & 33 \\
\hline P. synxantha CIP $5922^{\mathrm{T}}$ & 26 & 23 \\
\hline P. corrugata ATCC $29736^{\mathrm{T}}$ & 15 & 14 \\
\hline
\end{tabular}

* The unrelatedness of $P$. fluorescens biovar IV strain DSMZ 50148, $P$. putida biovar B strain ATCC 17484 and CIP $105470^{\mathrm{T}}$ was confirmed by $\Delta T_{\mathrm{m}}$ values of $13{ }^{\circ} \mathrm{C}$.

and CFML $95-321^{\mathrm{T}}$ and members of phenotypic groups XIIIb, XVa and XVc delineated two homogeneous groups.

When the DNA of strain CFML $95-251^{\mathrm{T}}$ was used as the labelled probe, 13 strains, including members of both subclusters XVa and XVc, formed a genotypically homogeneous group, showing DNA similarity values of $71-100 \%$. Even if these strains did not belong to the same phenotypic subcluster, subclusters XVa and XVc are closely related since they were included in the same phenotypic cluster, XV (Verhille et al., 1997). The $\Delta T_{\mathrm{m}}$ values calculated for hybrids were $2{ }^{\circ} \mathrm{C}$ and less, supporting a high level of relatedness between these strains.

Ten of 12 strains of phenotypic subcluster XIIIb shared a high level of DNA relatedness (74-100\%) with DNA of strain CFML 95-321 ${ }^{\mathrm{T}}$, used as the labelled probe. The $\Delta T_{\mathrm{m}}$ values within this genomic group were $2{ }^{\circ} \mathrm{C}$ or less, indicating that these organisms were closely related. Only two strains from this phenotypic subcluster, CFML 95-326 and CFML 95-323, showed low DNA similarities with CFML 95-321 ${ }^{\mathrm{T}}$. They were consequently removed from the genomic group. These two strains were phenotypically very similar to members of subcluster XIIIIb, although two phenotypic characteristics were found to differentiate these strains from the others. Neither of these strains was able to utilize $N$-acetyl D-glucosamine or tricarballylate as carbon sources. Furthermore, the inability to assimilate 2-keto-D-gluconate differentiated strain CFML 95-323 from all other members of phenotypic subcluster XIIIb. Reciprocal DNA hybridization values obtained between the two above groups ranged from 16 to $33 \%$, indicating that they formed two separate genomic groups.

In conclusion, levels of hybridization between strains CFML 95-32 $1^{\mathrm{T}}$ and CFML 95-251 ${ }^{\mathrm{T}}$ and other members of the genus Pseudomonas were low. The highest values obtained were between Pseudomonas fluorescens biovar V strain DSMZ 50148 and Pseudomonas putida biovar B strain ATCC 1784 and CFML 95-321 ${ }^{\mathrm{T}}$ (55 and $34 \%$, respectively). Their unrelatedness was confirmed by a $\Delta T_{\mathrm{m}}$ value of $13^{\circ} \mathrm{C}$.

According to the above results, the strains that formed these two genomic groups were sufficiently closely related to warrant recognition as members of two separate species, for which we propose the names $P$. gessardii sp. nov. (type strain CIP $105469^{\mathrm{T}}=\mathrm{CFML}$ 95-251 ${ }^{\mathrm{T}}$ ) and $P$. migulae sp. nov. (type strain CIP $105470^{\mathrm{T}}=$ CFML 95-321 ${ }^{\mathrm{T}}$ ).

Ideally, the species should be phenotypically distinct, so that species definition can be performed easily. Fourteen phenotypic features were found to differentiate the two new species from each other. $P$. gessardii strains assimilated L-arabitol, xylitol, myoinositol, adonitol and meso-erythritol. On the other hand, P. migulae strains utilized the following com- 


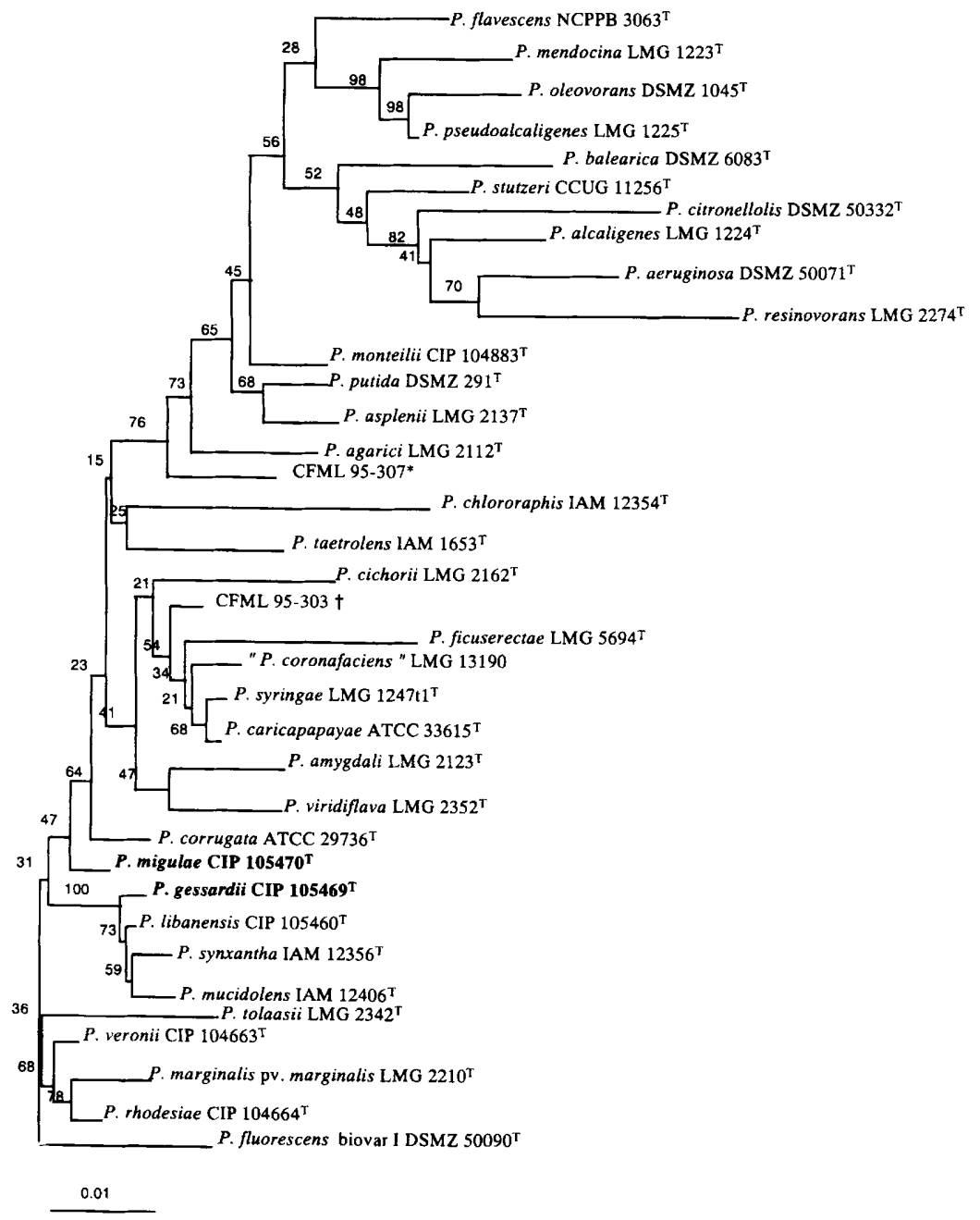

Fig. 2. Phylogenetic position of $P$. gessardii and $P$. migulae within the genus Pseudomonas, derived from 165 rRNA sequences. Numbers at branch-points represent percentage frequencies at which given branches appeared in 1000 bootstrap replications. Evolutionary distance is represented only in the horizontal direction. Strains indicated by * and $t$ belong to phenotypic cluster IX of Verhille et al. (1997).

pounds as carbon sources: L-arabinose, D-xylose, D-saccharate, meso-tartrate, tricarballylate, D-glucuronate, D-galacturonate, phenylacetate and histamine. Variable characteristics among strains of $P$. gessardii and $P$. migulae are given in Tables 5 and 6 , respectively. The two new species could also be differentiated from $P$. veronii (Elomari et al., 1997), $P$. rhodesiae (Coroler et al., 1996) and $P$. libanensis (Dabboussi et al., 1999) and from other Pseudomonas species (Palleroni, 1984) by various phenotypic characteristics listed in Table 7.

The highest 16S rDNA identities (99\% and more) measured between $P$. gessardii CIP $105469^{\mathrm{T}}, P$. migulae CIP $105470^{\mathrm{T}}$ and Pseudomonas type strains listed by Kersters et al. (1996) were not supported by high DNA-DNA hybridization levels (less than $36 \%$, see Table 4). In fact, DNA-DNA hybridization remains the optimal method for measuring the degree of relatedness between closely related organisms (Fox et al., 1992; Stackebrandt \& Goebel, 1994). However, the phylogenetic tree displayed in Fig. 2 clearly demonstrates that $P$. gessardii CIP $105469^{\mathrm{T}}$ and $P$. migulae CIP $105470^{\mathrm{T}}$ belong to the 'Pseudomonas fluorescens intrageneric cluster', as it has been described by Moore et al. (1996). On the basis of the above physiological, biochemical and genotypic characteristics, we describe the following two new species.

\section{Description of Pseudomonas gessardii sp. nov.}

Pseudomonas gessardii (ges.sar'di.i. M.L. gen. masc. $n$. gessardii after C. Gessard, who isolated 'Bacterium aeruginosum' for the first time and studied its pigment).

Cells are asporogeneous, rod-shaped and stain Gramnegative. Cells are motile by means of one polar flagellum. Pyoverdin is produced on King B medium and on S1 medium (Gould et al., 1985). No phenazine pigments are observed on King A medium. Cells are oxidase- and catalase-positive. Cetrimide ( $N$-acetyl$N, N, N$-trimethylammonium) is assimilated. Significant growth is observed only at low salt concentrations (up to $0.8 \%$ ) and not at 5 or $7 \%$. Strains grow at $4{ }^{\circ} \mathrm{C}$ and not at $41^{\circ} \mathrm{C}$. Levan is produced from sucrose. Starch and $o$-nitrophenyl $\beta$-D-galactopyranoside cannot be assimilated. Does not form indole from tryptophan. Does not decarboxylate lysine or ornithine. 
Table 5. Variable characteristics among 13 strains of $P$. gessardii

\begin{tabular}{|c|c|c|}
\hline Characteristic & $\begin{array}{l}\text { Reaction of } \\
\text { majority } \\
\text { of strains* }\end{array}$ & $\begin{array}{l}\text { Reaction of } \\
\text { CIP } 105469^{T}\end{array}$ \\
\hline \multicolumn{3}{|l|}{ Conventional tests } \\
\hline Nitrate reduction, tetrathionate reductase & $+(1)$ & + \\
\hline Growth on $3 \% \mathrm{NaCl}$ & $+(1)$ & - \\
\hline Growth on 2,3,5-triphenyltetrazolium chloride & $-(1)$ & - \\
\hline Malonate assimilation, denitrification, Tween esterase & $+(2)$ & + \\
\hline Gelatin liquefaction, urease, haemolysin & $-(2)$ & - \\
\hline Lecithinase production & $+(3)$ & + \\
\hline Tributyrin esterase & $+(5)$ & - \\
\hline \multicolumn{3}{|l|}{ Carbon sources } \\
\hline Tryptamine, D-mannose & $+(1)$ & + \\
\hline DL- $\alpha$-Amino- $n$-valerate & $+(2)$ & - \\
\hline D-Malate & $-(2)$ & - \\
\hline Gentisate, mucate & $+(3)$ & + \\
\hline$m$-Hydroxybenzoate, benzoate & $+(4)$ & + \\
\hline$p$-Hydroxybenzoate & $+(4)$ & - \\
\hline D-Galactose & $+(5)$ & + \\
\hline Ethanolamine & $+(6)$ & - \\
\hline Itaconate & $+(2)$ & + \\
\hline trans-Aconitate & $-(1)$ & - \\
\hline \multicolumn{3}{|l|}{ Enzymic tests } \\
\hline $\begin{array}{l}N \text {-Acetyl- } \beta \text {-D-glucosaminidase, } N \text {-carboxybenzoxy-arginine- } \\
\text { 4-methoxy-arylamidase }\end{array}$ & $-(5)$ & - \\
\hline $\begin{array}{l}\text { Esterase-C4, esterase-C12, esterase-C14, } \alpha \text {-L-glutamate } \\
\text { arylamidase, L-ornithine arylamidase, L-serine arylamidase, } \\
\text { L-lysyl-L-alanine arylamidase, L-alanyl-L-phenylalanyl-L- } \\
\text { proline arylamidase, L-alanyl-L-phenylalanyl-L-prolyl-L- } \\
\text { alanine arylamidase, L-seryl-L-methionine arylamidase, L- } \\
\text { phenylalanyl-L-arginine arylamidase, L-phenylalanyl-L- } \\
\text { prolyl-L-alanine arylamidase }\end{array}$ & $+(1)$ & + \\
\hline $\begin{array}{l}S \text {-Benzyl-cysteine arylamidase, L-histidyl-L-leucyl-L-histidine } \\
\text { arylamidase }\end{array}$ & $-(1)$ & - \\
\hline $\begin{array}{l}\text { Esterase-C16, L-prolyl-L-arginine arylamidase, L-lysyl-L- } \\
\text { serine-4-methoxy arylamidase }\end{array}$ & $-(2)$ & - \\
\hline $\begin{array}{l}\text { L-Threonine arylamidase, L-histidyl-L-serine arylamidase, L- } \\
\text { leucyl-L-alanine arylamidase, L-lysyl-L-lysine arylamidase, } \\
\text { L-histidyl-L-phenylalanine arylamidase, L-valyl-L-tyrosyl-L- } \\
\text { serine arylamidase }\end{array}$ & $+(2)$ & + \\
\hline L-Arginyl-L-arginine arylamidase & $+(3)$ & + \\
\hline L-Tyrosine arylamidase & $-(4)$ & - \\
\hline Leucyl-glycine arylamidase, L-isoleucine arylamidase & $+(4)$ & + \\
\hline L-Leucyl-L-leucyl-L-valyl-L-tyrosyl-L-serine arylamidase & $-(4)$ & + \\
\hline L-Histidine arylamidase, L-tryptophan arylamidase & $+(5)$ & + \\
\hline L-Aspartate arylamidase & $+(5)$ & - \\
\hline L-Hydroxyproline arylamidase & $-(6)$ & + \\
\hline Glycyl-proline arylamidase & $+(6)$ & + \\
\hline $\begin{array}{l}\alpha \text {-L-Glutamyl- } \alpha \text {-L-glutamic arylamidase, L-phenylalanyl-L- } \\
\text { proline arylamidase }\end{array}$ & $-(6)$ & - \\
\hline$\alpha$-L-Glutamyl-L-histidine arylamidase & $+(6)$ & + \\
\hline Glycyl-L-tryptophan arylamidase & $-(6)$ & + \\
\hline
\end{tabular}

* Numbers in parentheses are the numbers of strains differing from the more common result. 
Table 6. Variable characteristics among 10 strains of $P$. migulae

\begin{tabular}{|c|c|c|}
\hline Characteristic & $\begin{array}{l}\text { Reaction of } \\
\text { majority of } \\
\text { strains* }\end{array}$ & $\begin{array}{l}\text { Reaction of } \\
\text { CIP } \\
105470^{\mathrm{T}}\end{array}$ \\
\hline \multicolumn{3}{|l|}{ Conventional tests } \\
\hline Denitrification & $+(1)$ & + \\
\hline Urease, haemolysin & $-(1)$ & - \\
\hline $\begin{array}{l}\text { Nitrate reduction, growth on } 3 \% \mathrm{NaCl} \text {, malonate } \\
\text { assimilation }\end{array}$ & $\mathrm{C}(5)$ & + \\
\hline Tributyrin esterase & $+(2)$ & + \\
\hline \multicolumn{3}{|l|}{ Carbon sources } \\
\hline D-Tartrate, 3-phenylpropionate & $-(1)$ & - \\
\hline D-Malate, DL- $\alpha$-amino- $n$-valerate & $+(1)$ & + \\
\hline$\alpha$-Ketoglutarate & $+(2)$ & + \\
\hline \multicolumn{3}{|l|}{ Enzymic tests } \\
\hline $\begin{array}{l}N \text {-Acetyl- } \beta \text {-D-glucosaminidase, } \gamma \text {-glutamyltransferase, } \\
\text { tyrosyl-L-serine arylamidase, } \mathrm{L} \text {-phenylalanyl-L-arginine } \\
\text { arylamidase, } \mathrm{L} \text {-phenylalanyl-L-prolyl-L-alanine arylamidase }\end{array}$ & $+(1)$ & + \\
\hline Esterase-C5, esterase-C9, esterase- $\mathrm{C} 10$ & $+(1)$ & - \\
\hline $\begin{array}{l}\text { Esterase-C12, glycyl-proline arylamidase, } \alpha \text {-L-glutamate } \\
\text { arylamidase, } \alpha \text {-L-glutamyl-L-histidine arylamidase }\end{array}$ & $-(1)$ & - \\
\hline L-Pyrrolidone arylamidase & $-(2)$ & - \\
\hline L-Alanyl-L-phenylalanyl-L-proline arylamidase & $+(2)$ & + \\
\hline L-Alanyl-L-phenylalanyl-L-prolyl-L-alanine arylamidase & $+(2)$ & - \\
\hline$\alpha$-L-Aspartyl-L-arginine arylamidase & $-(2)$ & + \\
\hline L-Tyrosine arylamidase, L-alanyl-L-arginine arylamidase & $+(3)$ & + \\
\hline$S$-Benzyl-cysteine arylamidase & $-(3)$ & + \\
\hline$N$-Carboxybenzoxy-L-arginine-4-methoxy arylamidase & $+(3)$ & - \\
\hline Esterase-C4 & $+(4)$ & - \\
\hline L-Aspartate arylamidase & $-(4)$ & + \\
\hline L-Isoleucine arylamidase & $+(4)$ & + \\
\hline $\begin{array}{l}\text { Glycyl-L-arginine arylamidase, L-phenyl-L-proline } \\
\text { arylamidase }\end{array}$ & $-(4)$ & - \\
\hline $\begin{array}{l}\text { L-Hydroxyproline arylamidase, L-threonine arylamidase, L- } \\
\text { lysyl-L-lysine arylamidase }\end{array}$ & $\mathrm{c}(5)$ & + \\
\hline
\end{tabular}

* The numbers in parentheses are the numbers of strains differing from the more common result; $\mathrm{C}$, $50 \%$ of strains are positive.

No elastase, coagulase, $\beta$-xylosidase ( $p$-nitrophenyl $\beta$ $D$-xylopyranoside test) or phenylalanine deaminase activities are reported. No activity against DNA is noticed. Strains exhibit no acetyl-methyl-carbinol (acetoin) activity. Fibrinolysin test is negative.

All strains utilize the following substrates as carbon and energy sources: D-glucose, D-fructose, D-trehalose, D-ribose, D-arabitol, L-arabitol, xylitol, glycerol, myoinositol, D-mannitol, adonitol, meso-erythritol, Lmalate, cis-aconitate, citrate, 2-keto-D-gluconate, $\mathrm{N}$ acetyl D-glucosamine, D-gluconate, protocatechuate, quinate, betaine, putrescine, DL- $\alpha$-amino- $n$-butyrate, DL-lactate, caprate, caprylate, succinate, fumarate, glutarate, DL-glycerate, D-glucosamine, itaconate, DL- $\beta$-hydroxybutyrate, L-aspartate, L-glutamate, Lproline, D-alanine, L-alanine, L-serine, malonate, propionate, $\mathrm{L}$-tyrosine and 2-oxoglutarate. The following compounds are not utilized: L-sorbose, D-melibiose, sucrose, D-raffinose, maltotriose, maltose, $\alpha$-lactose, lactulose, 1-O-methyl $\beta$-galactopyranoside, 1-Omethyl $\alpha$-galactopyranoside, D-cellobiose, $\beta$-gentiobiose, 1- $O$-methyl $\beta$-D-glucopyranoside, aesculin, $\mathrm{L}$-arabinose, D-xylose, palatinose, $\alpha$-L-rhamnose, $\alpha$-Lfucose, D-melezitose, dulcitol, D-tagatose, maltitol, Dturanose, $\mathrm{D}$-sorbitol, hydroxyquinoline $\beta$-glucuronide, D-lyxose, 1- $O$-methyl $\alpha$-D-glucopyranoside, 3-Omethyl D-glucopyranose, D-saccharate, mucate, Ltartrate, D-tartrate, meso-tartrate, tricarballylate, D-glucuronate, D-galacturonate, 5-keto-D-gluconate, L-tryptophan, phenylacetate, 3-phenylpropionate, $m$-coumarate, trigonelline, histamine and L-histidine.

Strains have the following enzyme activities: esterases C5, C6, C8, C9 and C10, L-pyrrolidone arylamidase, Lphenylalanine arylamidase, L-lysine arylamidase, gly- 
Two new Pseudomonas species from mineral waters

Table 7. Characteristics that differentiate $P$. gessardii and $P$. migulae from other Pseudomonas strains

-, At least $90 \%$ of strains negative; d, 11-89\% of strains positive; + , at least $90 \%$ strains positive; ND, not determined.

\begin{tabular}{|c|c|c|c|c|c|c|c|c|c|c|c|c|c|c|}
\hline \multirow[t]{3}{*}{ Characteristic } & \multirow[t]{3}{*}{ P. gessardii } & \multirow[t]{3}{*}{ P. migulae } & \multirow[t]{3}{*}{ P. aeruginosa } & \multicolumn{5}{|c|}{ P. fluorescens biovars } & \multirow[t]{3}{*}{ P. chlororaphis } & \multirow{2}{*}{\multicolumn{2}{|c|}{$\begin{array}{c}\text { P. putida } \\
\text { biovars }\end{array}$}} & \multirow[t]{3}{*}{ P. veronii } & \multirow[t]{3}{*}{ P. rhodesiae } & \multirow[t]{3}{*}{ P. libanensis } \\
\hline & & & & \multirow{2}{*}{ I } & \multirow{2}{*}{ II } & \multirow{2}{*}{ III } & \multirow{2}{*}{ IV } & \multirow{2}{*}{$\mathbf{v}$} & & & & & & \\
\hline & & & & & & & & & & A & B & & & \\
\hline Pyocyanin production & - & - & + & - & - & - & - & - & - & - & - & - & - & - \\
\hline Denitrification & d & + & + & - & + & + & + & - & + & - & - & + & - & - \\
\hline Growth at $4{ }^{\circ} \mathrm{C}$ & + & + & - & + & + & + & + & d & + & d & + & + & + & + \\
\hline Growth at $41{ }^{\circ} \mathrm{C}$ & - & - & + & - & - & - & - & - & - & - & - & - & - & - \\
\hline Production of: & & & & & & & & & & & & & & \\
\hline Lecithinase & d & + & - & + & d & + & + & $\mathrm{d}$ & + & - & - & - & + & + \\
\hline Levan & + & + & - & + & + & - & + & - & + & - & - & + & + & + \\
\hline Gelatin liquefaction & - & - & + & + & + & + & + & + & + & - & - & d & - & ND \\
\hline Tween esterase & d & - & + & d & - & d & d & d & + & d & $\mathrm{d}$ & - & - & - \\
\hline Assimilation of: & & & & & & & & & & & & & & \\
\hline myo-Inositol & + & - & - & d & + & d & + & d & + & - & - & + & + & + \\
\hline Mucate & d & + & - & + & + & d & + & + & + & d & + & d & + & + \\
\hline Phenylacetate & - & + & - & - & -- & d & - & d & d & d & + & - & - & - \\
\hline L-Arabinose & - & + & - & + & + & d & + & d & - & d & + & + & + & + \\
\hline D-Trehalose & + & + & - & + & + & d & + & d & + & - & - & d & + & d \\
\hline D-Xylose & - & + & - & + & d & d & d & d & - & d & d & + & + & + \\
\hline D-Saccharate & - & + & - & + & + & $\mathrm{d}$ & + & d & + & + & + & ND & ND & + \\
\hline meso-Tartrate & - & + & - & - & - & d & - & d & - & d & - & - & - & $\mathrm{d}$ \\
\hline meso-Erythritol & + & - & - & d & d & + & - & d & - & - & - & + & - & + \\
\hline Adonitol & + & - & - & + & - & $\mathrm{d}$ & - & d & - & - & - & - & - & + \\
\hline D-Glucuronate & - & + & ND & ND & ND & ND & ND & ND & ND & ND & ND & ND & ND & + \\
\hline Tryptamine & + & - & - & - & d & $\mathrm{d}$ & - & - & - & d & + & - & - & - \\
\hline Itaconate & d & - & + & + & d & d & - & d & + & d & - & ND & ND & + \\
\hline$\alpha$-Aminobutyrate & + & + & - & - & - & - & - & - & - & - & d & + & + & + \\
\hline L-Histidine & - & - & + & + & d & + & + & d & + & + & + & d & + & - \\
\hline Xylitol & + & - & $\mathrm{ND}$ & ND & ND & $\mathrm{ND}$ & ND & ND & ND & $\mathrm{ND}$ & $\mathrm{ND}$ & ND & ND & + \\
\hline L-Tryptophan & - & - & d & + & $\mathrm{d}$ & $d$ & - & $d$ & + & - & + & + & - & - \\
\hline Histamine & - & + & + & $\mathrm{d}$ & - & d & - & d & d & d & + & - & - & - \\
\hline Trigonelline & - & - & - & d & d & d & - & d & - & d & + & + & - & - \\
\hline Tricarballylate & - & + & $\mathrm{ND}$ & ND & ND & $\mathrm{ND}$ & ND & ND & $\mathrm{ND}$ & $\mathrm{ND}$ & ND & ND & ND & - \\
\hline Benzoate & d & + & + & $\mathrm{d}$ & $d$ & $\mathrm{~d}$ & + & $\mathrm{d}$ & + & d & + & - & - & - \\
\hline D-Mannose & + & + & - & + & + & + & + & d & + & d & d & + & + & + \\
\hline D-Alanine & + & + & + & + & + & + & + & - & + & + & + & + & + & + \\
\hline Ethanolamine & d & + & d & + & d & d & + & d & d & d & d & + & + & + \\
\hline D-Galacturonate & - & + & ND & ND & ND & ND & ND & ND & ND & ND & ND & ND & ND & + \\
\hline D-Sorbitol & - & - & - & + & + & $\mathrm{d}$ & + & d & - & - & d & + & + & + \\
\hline D-Galactose & d & + & - & + & + & d & + & d & d & - & d & + & + & + \\
\hline Sucrose & - & - & - & + & + & - & + & d & + & - & d & + & - & - \\
\hline D-Malate & d & + & d & - & d & d & + & d & d & d & d & - & -- & $\mathrm{ND}$ \\
\hline L-Tartrate & - & - & - & - & - & - & + & - & $\mathrm{d}$ & $\mathrm{d}$ & d & - & - & ND \\
\hline L-Arabitol & + & - & No & ND & $\mathrm{ND}$ & ND & ND & ND & ND & ND & ND & - & - & + \\
\hline
\end{tabular}

cine arylamidase, L-arginine arylamidase, L-alanine arylamidase, $\gamma$-glutamyltransferase, methionine arylamidase, glycyl-glycine arylamidase, glycyl-phenylalanine arylamidase, L-seryl-tyrosine arylamidase, $\mathrm{L}$-glutamine arylamidase, $\mathrm{L}$-proline arylamidase, $\beta$-alanine arylamidase, $\mathrm{L}$-alanyl-L-arginine arylamidase, $\alpha$ $\mathrm{L}$-aspartyl-L-alanine arylamidase, $\alpha$-L-aspartyl-L-arginine arylamidase, glycyl-L-alanine arylamidase, glycylL-arginine arylamidase and $N$-carboxybenzoxy-glycylglycyl-L-arginine arylamidase. None of the strains possess the following enzyme activities: $\alpha$-D-galactosidase, $\beta$-D-galactosidase, phospho- $\beta$-D-galactosidase, $\alpha$-L-arabinosidase, $\alpha$-D-glucosidase, $\beta$-D-glucosidase, $\beta$-D-galacturonohydrolase, $\beta$-D-glucuronidase, $\alpha$-maltosidase, $\beta$-maltosidase, $N$-acetyl- $\alpha$-D-glucosaminidase, $\alpha$-L-fucosidase, $\beta$-D-fucosidase, $\beta$-L-fucosidase, $\beta$-D-lactosidase, $\alpha$-D-mannosidase, $\beta$-D-mannosidase, $\alpha$-D-xylosidase, $\beta$-D-xylosidase, esterase-C18, $\quad N$ benzoyl-leucine arylamidase, $N$-benzoyl-L-alanine-4- methoxy arylamidase, $N$-carboxybenzoxy-arginyl-4methoxy arylamidase, $N$-acetyl-glycyl-L-lysine arylamidase.

Temperatures for growth range from 4 to $35^{\circ} \mathrm{C}$ with an optimum at $30^{\circ} \mathrm{C}$. Strains were isolated from natural mineral waters. No clinical significance is known.

Pseudomonas gessardii sp. nov. as described includes 13 strains: the type strain, CIP $105469^{\mathrm{T}}(=$ CFML $95-$ $251^{\mathrm{T}}$ ), and the following other strains: CFML 95-244, CFML 95-332, CFML 95-258, CFML 95-338, CFML 95-250, CFML 95-256, CFML 95-264, CFML 95-254, CFML 95-245, CFML 95-342, CFML 95-331 and CFML 95-255. The above strains have been deposited in the Collection de la Faculté de Médecine, Lille, France (CFML) and the Collection de l'Institut Pasteur, Paris, France (CIP). 


\section{Description of Pseudomonas migulae sp. nov.}

Pseudomonas migulae (mi'gu.lae. M.L. gen. n. migulae after W. Migula, who defined the morphological properties of the genus Pseudomonas).

Colonies on nutrient agar are smooth and circular. Cells are Gram-negative and possess a single polar flagellum. Cells produce the characteristic fluorescent pigment on King B medium and on S1 medium (Gould et al., 1985) and possess catalase and oxidase activities. No phenazine pigments are produced on King A medium. Strains tolerate low salt concentrations (up to $0.8 \%$ ) but higher concentrations $(5$ and $7 \%$ ) inhibit growth. The 2,3,5-triphenyltetrazolium chloride, fibrinolysin and haemolysin tests are negative. No tetrathionate reductase or Tween esterase activities are reported. The Voges-Proskauer reaction (acetoin) is negative. Strains do not liquefy gelatin. $o$-Nitrophenyl $\beta$-D-galactopyranoside is not assimilated. Starch is not hydrolysed. Levan is produced from sucrose and strains possess an arginine decarboxylase activity. Cetrimide ( $N$-acetyl $N, N, N$-trimethylammonium) and L-tyrosine can be used for growth. Lysine and ornithine catabolism do not occur. Cells have no elastase, DNase, coagulase, phenylalanine deaminase, lecithinase or $\beta$-xylosidase ( $p$-nitrophenyl $\beta$-D-galactopyranoside) activities. No indole is formed from tryptophan. Growth occurs at $4{ }^{\circ} \mathrm{C}$ but is invariably negative at $41{ }^{\circ} \mathrm{C}$.

All strains utilize the following substrates as carbon and energy sources: D-glucose, D-fructose, D-galactose, D-trehalose, D-mannose, D-ribose, L-arabinose, Dxylose, D-arabitol, glycerol, D-mannitol, D-saccharate, mucate, meso-tartrate, L-malate, cis-aconitate, transaconitate, tricarballylate, citrate, D-glucuronate, Dgalacturonate, $N$-acetyl D-glucosamine, 2-ketoD-gluconate, D-gluconate, phenylacetate, protocatechuate, $p$-hydroxybenzoate, quinate, betaine, benzoate, putrescine, DL- $\alpha$-amino- $n$-butyrate, histamine, DL-lactate, caprate, caprylate, succinate, fumarate, glutarate, DL-glycerate, ethanolamine, D-glucosamine, DL- $\beta$-hydroxybutyrate, L-aspartate, L-glutamate, Lproline, D-alanine, L-alanine, L-serine, malonate, propionate and L-tyrosine. The following compounds are not utilized: L-sorbose, D-melibiose, sucrose, Draffinose, maltotriose, maltose, $\alpha$-lactose, lactulose, 1 $O$-methyl $\beta$-galactopyranoside, $1-O$-methyl $\alpha$-galactopyranoside, D-cellobiose, $\beta$-gentiobiose, 1- $O$-methyl $\beta$-D-glucopyranoside, aesculin, palatinose, $\alpha$-Lrhamnose, $\alpha$-L-fucose, D-melezitose, L-arabitol, xylitol, dulcitol, D-tagatose, myo-inositol, maltitol, Dturanose, D-sorbitol, adonitol, hydroxyquinoline $\beta$ glucuronide, D-lyxose, meso-erythritol, 1-O-methyl $\alpha$-D-glucopyranoside, 3- $O$-methyl D-glucopyranose, Ltartrate, 5-keto-D-gluconate, L-tryptophan, gentisate, $m$-hydroxybenzoate, $m$-coumarate, trigonelline, Lhistidine, tryptamine and itaconate.

All strains have the following enzyme activities: esterase-C6, esterase-C8, L-phenylalanine arylamidase, L-lysine arylamidase, L-histidine aryl- amidase, glycine arylamidase, L-arginine arylamidase, L-alanine arylamidase, methionine arylamidase, glycyl-glycine arylamidase, glycyl-phenylalanine arylamidase, leucyl-glycine arylamidase, L-seryl-L-tyrosine arylamidase, L-glutamine arylamidase, L-ornithine arylamidase, L-proline arylamidase, L-serine arylamidase, L-tryptophan arylamidase, $\beta$-alanine arylamidase, $\alpha$-L-aspartyl-L-alanine arylamidase, glycyl-Lalanine arylamidase, glycyl-L-tryptophan arylamidase, L-leucyl-L-alanine arylamidase, L-seryl-L-methionine arylamidase, $N$-carboxybenzoxy-glycyl-glycyl-L-arginine arylamidase and L-histidyl-L-phenylalanine arylamidase. None of the strains possess the following enzymic activities: $\alpha$-D-galactosidase, $\beta$-D-galactosidase, phospho- $\beta$-D-galactosidase, $\alpha$-L-arabinosidase, $\alpha$-D-glucosidase, $\beta$-D-glucosidase, $\beta$-D-galacturonohydrolase, $\beta$-D-glucuronidase, $\alpha$-maltosidase, $\beta$ maltosidase, $\quad N$-acetyl- $\alpha$-D-glucosaminidase, $\quad \alpha$-Lfucosidase, $\beta$-D-fucosidase, $\beta$-L-fucosidase, $\beta$-D-lactosidase, $\alpha$-D-mannosidase, $\beta$-D-mannosidase, $\alpha$-D-xylosidase, $\beta$-D-xylosidase, esterase-C14, esterase-C16, esterase-C18, $N$-benzoyl-leucine arylamidase, Larginyl-L-arginine arylamidase, $\alpha$-L-glutamyl- $\alpha$-L-glutamic arylamidase, L-histidyl-L-leucyl-L-histidine arylamidase, L-histidyl-L-serine arylamidase, L-leucyl-Lleucyl-L-valyl-L-tyrosyl-L-serine arylamidase, L-prolylL-arginine arylamidase, L-valyl-L-tyrosyl-L-serine arylamidase, $N$-benzoyl-L-alanine-4-methoxy arylamidase, $N$-acetyl-glycyl-L-lysine arylamidase and L-lysyl-L-serine-4-methoxy arylamidase.

Temperatures for growth range from 4 to $35^{\circ} \mathrm{C}$, with an optimum at $30^{\circ} \mathrm{C}$. Strains examined in this study were isolated exclusively from natural mineral waters. No clinical significance is known.

The following 10 strains are included in Pseudomonas migulae sp. nov.: the type strain, CIP $105470^{\mathrm{T}}(=$ CFML 95-321 ${ }^{\mathrm{T}}$ ), CFML 95-341, CFML 95-320, CFML 95-318, CFML 95-327, CFML 95-316, CFML 95-333, CFML 95-324, CFML 95-317 and CFML 95263. The above strains have been deposited in the Collection de la Faculté de Médecine, Lille, France (CFML) and the Collection de l'Institut Pasteur, Paris, France (CIP).

\section{ACKNOWLEDGEMENTS}

We thank P. A. D. Grimont for his help in the interpretation of RNA sequencing data.

\section{REFERENCES}

Baldani, J. I., Pot, B., Kirchhof, G. \& 8 other authors (1996). Emended description of Herbaspirillum; inclusion of [Pseudomonas] rubrisubalbicans, a mild plant pathogen, as Herbaspirillum rubrisubalbicans comb. nov.; and classification of a group of clinical isolates (EF group 1) as Herbaspirillum species 3. Int J Syst Bacteriol 46, 802-810.

Beji, A., Izard, D., Gavini, F., Leclerc, H., Leseine-Delstanche, M. \& Krembel, J. (1987). A rapid chemical procedure for isolation and purification of chromosomal DNA from gram-negative bacilli. Anal Biochem 162, 18-23.

Bowman, J. P., Sly, L. I., Hayward, A. C., Spiegel, Y. \& Stacke- 
brandt, E. (1993). Telluria mixta (Pseudomonas mixta Bowman, Sly, and Hayward 1988) gen. nov., comb. nov., and Telluria chitinolytica sp. nov., soil-dwelling organisms which actively degrade polysaccharides. Int $J$ Syst Bacteriol 43, 120-124.

Brosch, R., Lefevre, M., Grimont, F. \& Grimont, P. A. D. (1996). Taxonomic diversity of pseudomonads revealed by computerinterpretation of ribotyping data. Syst Appl Microbiol 19, 541-555.

Coroler, L., Elomari, M., Hoste, B., Gillis, M., lzard, D. \& Leclerc, H. (1996). Pseudomonas rhodesiae sp. nov., a new species isolated from natural mineral waters. Syst Appl Microbiol 19, 600-607.

Crosa, J. H., Brenner, D. J. \& Falkow, S. (1973). Use of a singlestrand specific nuclease for analysis of bacterial and plasmid deoxyribonucleic acid homo- and heteroduplexes. $J$ Bacteriol 115, 904-911.

Dabboussi, F., Hamze, M., Elomari, M., Verhille, S., Baida, N., Izard, D. \& Leclerc, H. (1999). Pseudomonas libanensis sp. nov., a new species isolated from Lebanese spring waters. Int $J$ Syst Bacteriol 49, 1091-1101.

De Ley, J. (1970). Reexamination of the association between melting point, buoyant density, and chemical base composition of deoxyribonucleic acid. $J$ Bacteriol 101, 738-754.

De Ley, J. (1992). The Proteobacteria: ribosomal RNA cistron similarities and bacterial taxonomy. In The Prokaryotes, 2nd edn, vol. 2, pp. 2109-2140. Edited by A. Balows, H. G. Trüper, M. Dworkin, W. Harder \& K. H. Schleifer. New York: Springer.

De Vos, P., Kersters, K., Falsen, E., Pot, B., Gillis, M., Segers, P. \& De Ley, J. (1985). Comamonas Davis and Park 1962 gen. nov., nom. rev. emend., and Comamonas terrigena Hugh 1962 sp. nov., nom. rev. Int $J$ Syst Bacteriol 35, 443-453.

Edwards, U., Rogall, T., Blöcker, H., Emde, M. \& Böttger, E. C. (1989). Isolation and direct complete nucleotide determination of entire genes. Characterization of a gene coding for $16 \mathrm{~S}$ ribosomal RNA. Nucleic Acids Res 17, 7843-7853.

Elomari, M., Coroler, L., Hoste, B., Gillis, M., Izard, D. \& Leclerc, H. (1996). DNA relatedness among Pseudomonas strains isolated from natural mineral waters and proposal of Pseudomonas veronii sp. nov. Int J Syst Bacteriol 46, 1138-1144.

Elomari, M., Coroler, L., Verhille, S., Izard, D. \& Leclerc, H. (1997). Pseudomonas monteillii sp. nov., isolated from clinical specimens. Int J Syst Bacteriol 47, 846-852.

Felsenstein, J. (1985). Confidence limits on phylogenies: an approach using the bootstrap. Evolution 39, 783-791.

Fox, G. E., Wisotzkey, J. D. \& Jurtshuk, P., Jr (1992). How close is close: 16S rRNA sequence identity may not be sufficient to guarantee species identity. Int J Syst Bacteriol 42, 166-170.

Gould, W. D., Hagedorn, C., Bardinelli, T. R. \& Zablotow, R. H. (1985). New selective media for enumeration and recovery of fluorescent pseudomonads from various habitats. Appl Environ Microbiol 49, 28-32.

Grimont, P. A. D., Popoff, M. Y., Grimont, F., Coynault, C. \& Lemelin, M. (1980). Reproducibility and correlation study of three deoxyribonucleic acid hybridization procedures. Curr Microbiol 4, 325-330.

Hoeniger, J. F. M. (1965). Development of flagella by Proteus mirabilis. $J$ Gen Microbiol 40, 29-42.

Holmes, B., Steigerwalt, A. G., Weaver, R. E. \& Brenner, D. J. (1987). Chryseomonas luteola comb. nov. and Flavimonas oryzihabitans gen. nov., comb. nov., Pseudomonas-like species from human clinical specimens and formerly known, respectively, as groups Ve-1 and Ve-2. Int J Syst Bacteriol 37, 245-250.
Kersters, K., Ludwig, W., Vancanneyt, M., De Vos, P., Gillis, M. \& Schleifer, K. H. (1996). Recent changes in the classification of the pseudomonads: an overview. Syst Appl Microbiol 19, 465-477. van der Kooij, D. (1990). Growth measurements with Pseudomonas aeruginosa, Aeromonas hydrophila and autochthonous bacteria to determine the biological stability of drinking water. Riv Ital Ig 5-6, 375-382.

Meyer, O., Stackebrandt, E. \& Auling, G. (1993). Reclassification of ubiquinone Q-10 containing carboxidotrophic bacteria: transfer of '(Pseudomonas) carboxydovorans' OM5 $5^{\mathrm{T}}$ to Oligotropha, gen. nov., as Oligotropha carboxydovorans, comb. nov., transfer of '(Alcaligenes) carboxydus' DSM $1086^{\mathrm{T}}$ to Carbophilus, gen. nov., as Carbophilus carboxidus, comb. nov., transfer of '(Pseudomonas) compransoris' DSM1231 $1^{\mathrm{T}}$ to Zavarzinia gen. nov., as Zavarzinia compransoris, comb. nov., and emended descriptions of the new genera. Syst Appl Microbiol 16, 390-395.

Migula, W. (1894). Über ein neues System der Bakterien. Arb Bakteriol Inst Karlsruhe 1, 235-238.

Moore, E. R. B., Mau, M. , Arnscheidt, A., Böttger, E. C., Hutson, R. A., Collins, M. D., Van De Peer, Y., De Wachter, R. \& Timmis, K. N. (1996). The determination and comparison of the $16 \mathrm{~S}$ rRNA gene sequence of species of the genus Pseudomonas (sensu stricto) and estimation of the natural intrageneric relationships. Syst Appl Microbiol 19, 478-492.

Nakagawa, Y., Sakane, T. \& Yokota, A. (1996). Transfer of 'Pseudomonas riboflavina' (Foster 1944), a Gram-negative, motile rod with long-chain 3-hydroxy fatty acids, to Devosia riboflavina gen. nov., sp. nov., nom. rev. Int J Syst Bacteriol 46, 16-22.

Oger, C., Hernandez, J. F., Delattre, J. M., Delabroise, A. H. \& Krupsky, S. (1987). Etude par épifluorescence de l'évolution de la microflore totale dans une eau minérale embouteillée. Water Res 21, 469-474.

Palleroni, N. J. (1984). Genus I. Pseudomonas Migula 1894, $237^{\mathrm{AL}}$. In Bergey's Manual of Systematic Bacteriology, vol. 1, pp. 141-199. Edited by N. R. Krieg \& J. G. Holt. Baltimore: Williams \& Wilkins.

Palleroni, N. J. \& Bradbury, J. F. (1993). Stenotrophomonas, a new bacterial genus for Xanthomonas maltophilia (Hugh 1980) Swings et al. 1983. Int J Syst Bacteriol 43, 606-609.

Palleroni, N. J., Kunisawa, R., Contopoulou, R. \& Doudoroff, M. (1973). Nucleic acid homologies in the genus Pseudomonas. Int $J$ Syst Bacteriol 23, 333-339.

Saitou, N. \& Nei, M. (1987). The neighbor-joining method: a new method for reconstructing phylogenetic trees. Mol Biol Evol 4, $406-425$.

Schwaller, P. \& Schmidt-Lorenz, W. (1981). La filore microbienne de quatre eaux minérales non gazéifiées et mises en bouteilles. $2^{e}$ communication: les Pseudomonas et autres bactéries à Gram négatif. Composition fine de la flore. Zbl Bakteriol Mikrobiol Hyg 1 Abt Orig C 2, 179-196.

Segers, P., Vancanneyt, M., Pot, B., Torck, U., Hoste, B., Dewettinck, D., Falsen, E., Kersters, K. \& De Vos, P. (1994). Classification of Pseudomonas diminuta Leifson and Hugh 1954 and Pseudomonas vesicularis Büsing, Döll, and Freytag 1953 in Brevundimonas gen. nov, as Brevundimonas diminuta comb. nov. and Brevundimonas vesicularis comb. nov., respectively. Int $J$ Syst Bacteriol 44, 499-510.

Stackebrandt, E. \& Goebel, B. M. (1994). Taxonomic note: a place for DNA-DNA reassociation and 16S rRNA sequence analysis in the present species definition in bacteriology. Int $J$ Syst Bacteriol 44, 846-849. 
Stanier, R. Y., Palleroni, N. J. \& Doudoroff, M. (1966). The aerobic pseudomonads: a taxonomic study. $J$ Gen Microbiol 43, 159-271.

Thompson, J. D., Higgins, D. G. \& Gibson, T. J. (1994). CLUSTAL $\mathrm{W}$ : improving the sensitivity of progressive multiple sequence alignment through sequence weighting, position-specific gap penalties and weight matrix choice. Nucleic Acids Res 22, 4673-4680.

Urakami, T., Araki, H., Oyanagi, H., Suzuki, K.-I. \& Komagata, K. (1992). Transfer of Pseudomonas aminovorans (den Dooren de Jong 1926) to Aminobacter gen. nov. as Aminobacter aminovorans comb. nov. and description of Aminobacter aganoensis sp. nov. and Aminobacter niigataensis sp. nov. Int $J$ Syst Bacteriol 42, 84-92.

Vandamme, P., Pot, B., Gillis, M., de Vos, P., Kersters, K. \& Swings, J. (1996). Polyphasic taxonomy, a consensus approach to bacterial systematics. Microbiol Rev 60, 407-438.

Verhille, S., Elomari, M., Coroler, L., Izard, D. \& Leclerc, H. (1997). Phenotypically based taxonomy of fluorescent Pseudomonas strains isolated from four natural mineral waters. Syst Appl Microbiol 20, 137-149.

Wayne, L. G., Brenner, D. J., Colwell, R. R. \& 9 other authors (1987). Report of the ad hoc committee on the reconciliation of approaches to bacterial systematics. Int J Syst Bacteriol 37, 463-464.

Willems, A., Busse, J., Goor, M. \& 8 other authors (1989). Hydrogenophaga, a new genus of hydrogen-oxidizing bacteria that includes Hydrogenophaga flava comb. nov. (formerly Pseudomonas flava), Hydrogenophaga palleronii (formerly
Pseudomonas palleronii), Hydrogenophaga pseudoflava (formerly Pseudomonas pseudoflava and 'Pseudomonas carboxydoflava'), and Hydrogenophaga taeniospiralis (formerly Pseudomonas taeniospiralis). Int $J$ Syst Bacteriol 39, 319-333.

Willems, A., Falsen, E., Pot, B., Jantzen, E., Hoste, B., Vandamme, P., Gillis, M., Kersters, K. \& De Ley, J. (1990). Acidovorax, a new genus for Pseudomonas facilis, Pseudomonas delafieldii, E. Falsen (EF) group 13, EF group 16, and several clinical isolates, with the species Acidovorax facilis comb. nov., Acidovorax delafieldii comb. nov., and Acidovorax temperans sp. nov. Int $J$ Syst Bacteriol 40, 384-398.

Yabuuchi, E., Yano, I., Oyaizu, H., Hashimoto, Y., Ezaki, T. \& Yamamoto, H. (1990). Proposals of Sphingomonas paucimobilis gen. nov. and comb. nov., Sphingomonas parapaucimobilis sp. nov., Sphingomonas yanoikuyae sp. nov., Sphingomonas adhaesiva sp. nov., Sphingomonas capsulata comb. nov., and two genospecies of the genus Sphingomonas. Microbiol Immunol 34, 99-119.

Yabuuchi, E., Kosako, Y., Oyaizu, H., Yano, I., Hotta, H., Hashimoto, Y., Ezaki, T. \& Arakawa, M. (1992). Proposal of Burkholderia gen. nov. and transfer of seven species of the genus Pseudomonas homology group II to the new genus, with the type species Burkholderia cepacia (Palleroni and Holmes 1981) comb. nov. Microbiol Immunol 36, 1251-1275.

Yabuuchi, E., Kosako, Y., Yano, I., Hotta, H. \& Nishiuchi, Y. (1995). Transfer of two Burkholderia and an Alcaligenes species to Ralstonia gen. nov.: proposal of Ralstonia pickettii (Ralston, Palleroni and Doudoroff 1973) comb. nov., Ralstonia solanacearum (Smith 1896) comb. nov. and Ralstonia eutropha (Davis 1969) comb. nov. Microbiol Immunol 39, 897-904. 